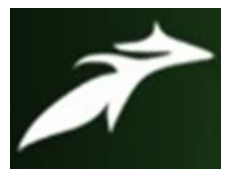

Poreddy Dileep et al, International Journal of Advances in Agricultural Science and Technology,

Vol.7 Issue.12, December-2020, pg. 1-8

ISSN: 2348-1358

Impact Factor: 6.057

NAAS Rating: 3.77

\title{
KNOWLEDGE OF THE BENEFICIARIES AND NON BENEFICIARIES TOWARDS ACTIVITIES OF KISAN CALL CENTERS
}

\author{
${ }^{1}$ Poreddy Dileep; ${ }^{2}$ Dr. Dipak Kumar Bose; ${ }^{3}$ Dr. Jahanara \\ ${ }^{1}$ M.Sc.Ag (Agricultural Extension \& Communication) \\ ${ }^{2}$ Associate Professor (Department of Agricultural Extension and Communication) \\ ${ }^{3}$ HOD Department of Agricultural Extension and Communication \\ Sam Higginbottom University of Agricultural Technology and Sciences, Prayagraj (211007)
}

DOI: 10.47856/ijaast.2020.v07i12.001

\begin{abstract}
Government and private organizations are engaged in providing knowledge based information on agriculture to farmers through ICT based applications. It includes farmers portal and kisan call centers (KCCs). These portals are facilitating dissemination of information and advisories to farmers. These portals, mobiles based platforms and kisan call services, can be integrated together to disseminate knowledge based information among farmers effectively. Kisan call centers is one of the best sources to have two wave communications with the farmers and scientists at around the all over India with a toll free number providing services through the year. The extent of utilization of these services depends on the farmers attitude towards kisan call centers. The study revealed that most of the respondents (55.00\%) had medium level of knowledge followed by low (13.33\%) and high (31.66\%) \& respondents (68.33\%) had medium level of attitude followed by high (20.00\%) and low (11.66\%).

Keywords: KCCs; Knowledge; Attitude.
\end{abstract}

\section{INTRODUCTION}

India is basically an agricultural country and agriculture sector accounts for about $15.96 \%$ of the GDP and employs $43.21 \%$ of the total workforce.

In order to harness the potential of ICT in Agriculture, Ministry of Agriculture launched the scheme "Kisan Call Centers (KCCs)" on January 21 ${ }^{\text {st }}$, 2004. Main aim of the project is to answer farmers" queries on a telephone call on their own dialect. These call centers are working in 14 different locations covering all the states and Uts. A countrywide common toll free number 1800-180-1551has been allotted for kisan call center this number is accessible through mobile phones and landlines of all telecom networks including private service provides. Replies queries are given in 22 local languages. 


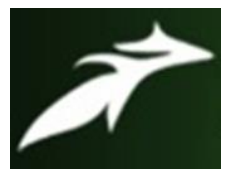

Poreddy Dileep et al, International Journal of Advances in Agricultural Science and Technology, Vol.7 Issue.12, December-2020, pg. 1-8

ISSN: 2348-1358

Impact Factor: 6.057

NAAS Rating: 3.77

\section{RESEARCH METHODOLOGY}

Ex-post facto research design was used for the present study. Ex-post - facto research design is an inquiry in which the researcher does not have direct control of independent variable because their manifestations occurred and they cannot be manipulated. Influences about relations among variable are made without intervention from concomitant variation of independent and dependent variable. The state of Telangana is divided into 31 administrative districts. Out of these, Karimnagar District is purposively selected for this study. In Karimnagar district comprises of 16 mandal, Jammikunta mandal of Karimnagar district of the Telangana state is selected through purposive sampling for the present study because adequate number of farmers are involve in KCCs. Jammikunta mandal was comprises of 58 villages, Out of these 58 villages, 6 villages were selected on the basis of KCCs by the selected respondents. Two types of farmers were selected in equal number from the each selected village who were using KCCs technology. From each selected villages, Twenty respondents were selected randomly thus making a total sample of 120.

\section{STATISTICAL ANALYSIS OF DATA:}

The data collected through interview schedule were transferred on the master sheet to describe characteristics of the respondents. For various items, frequencies were counted and percentage was calculated. To interpret the results and to show the relationship between independent variable and dependent variables, Mean, Frequency, Percentage, Co-efficient correlation was followed.

\section{RESULTS AND DISCUSSION}

Table 1: Socio-economic profile of the respondents

$\mathbf{N}=\mathbf{1 2 0}$

\begin{tabular}{|c|c|c|c|c|c|c|}
\hline \multirow{3}{*}{ S. No } & \multirow{3}{*}{ Characteristics } & \multirow{3}{*}{ Category } & \multicolumn{4}{|c|}{ Response } \\
\hline & & & \multicolumn{2}{|c|}{ Beneficiary } & \multicolumn{2}{|c|}{ Non-Beneficiary } \\
\hline & & & $F$ & $\%$ & $F$ & $\%$ \\
\hline \multirow{3}{*}{1.} & \multirow{3}{*}{ Age (in years) } & Young (<35 years) & 18 & 30.00 & 30 & 50.00 \\
\hline & & Middle (36-50 years) & 34 & 56.66 & 25 & 41.66 \\
\hline & & Old (>50 years) & 8 & 13.33 & 3 & 5.00 \\
\hline
\end{tabular}




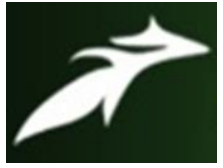

Poreddy Dileep et al, International Journal of Advances in Agricultural Science and Technology,

Vol.7 Issue.12, December-2020, pg. 1-8

ISSN: 2348-1358

Impact Factor: 6.057

NAAS Rating: 3.77

\begin{tabular}{|c|c|c|c|c|c|c|}
\hline \multirow{5}{*}{2} & \multirow{5}{*}{ Education level } & Illiterate & 18 & 30.00 & 38 & 63.33 \\
\hline & & Primary school & 15 & 25.00 & 12 & 20.00 \\
\hline & & High school & 11 & 18.33 & 7 & 11.66 \\
\hline & & intermediate & 8 & 13.33 & 3 & 5.00 \\
\hline & & Graduation \& above & 8 & 13.33 & & \\
\hline \multirow{4}{*}{3.} & \multirow{4}{*}{ Occupation } & Farming only & 8 & 13.33 & 22 & 36.66 \\
\hline & & Farming + Service & 14 & 23.33 & 17 & 28.33 \\
\hline & & Farming + Business & 18 & 30.00 & 11 & 18.33 \\
\hline & & $\begin{array}{l}\text { Farming }+ \text { Service }+ \\
\text { Business }\end{array}$ & 20 & 33.33 & 10 & 16.66 \\
\hline \multirow{4}{*}{4.} & \multirow{4}{*}{ Caste } & General & 5 & 8.33 & 7 & 11.66 \\
\hline & & $\mathrm{OBC}$ & 30 & 50.00 & 37 & 61.66 \\
\hline & & $\mathrm{SC}$ & 12 & 20.00 & 12 & 20.00 \\
\hline & & ST & 13 & 21.66 & 4 & 6.66 \\
\hline \multirow[b]{2}{*}{5.} & \multirow[b]{2}{*}{ Family type } & Nuclear & 48 & 80.00 & 49 & 81.66 \\
\hline & & Joint & 12 & 20.00 & 11 & 18.33 \\
\hline \multirow{3}{*}{6.} & \multirow{3}{*}{ Family size } & Up to 4 Members & 48 & 80.00 & 49 & 81.66 \\
\hline & & Above $>5$ Members & 12 & 20.00 & 11 & 18.33 \\
\hline & & & & & & \\
\hline & & & & & & \\
\hline
\end{tabular}




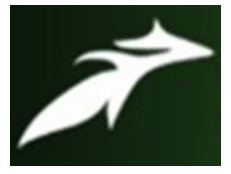

Poreddy Dileep et al, International Journal of Advances in Agricultural Science and Technology, Vol.7 Issue.12, December-2020, pg. 1-8

ISSN: 2348-1358

Impact Factor: 6.057

NAAS Rating: 3.77

\begin{tabular}{|l|l|l|l|l|l|l|}
\hline 7. & Type of house & Hut & 2 & 3.33 & 4 & 6.66 \\
\cline { 3 - 7 } & & Semi cemented & 27 & 45.00 & 38 & 63.33 \\
\cline { 3 - 7 } & Cemented & 31 & 51.66 & 18 & 30.00 \\
\hline \multirow{4}{*}{8.} & & & & 21.67 & 41 & 68.33 \\
\hline \multirow{3}{*}{} & Land holding 1 ha & 14 & 23.33 & 15 & 25.00 \\
\cline { 3 - 7 } & & Above 2 ha & 33 & 55.00 & 4 & 6.66 \\
\cline { 3 - 7 } & & & & & \\
\hline
\end{tabular}

\begin{tabular}{|c|c|c|c|c|c|c|}
\hline \multirow[b]{3}{*}{9.} & \multirow{3}{*}{$\begin{array}{l}\text { Annual Income } \\
\text { (Rs) }\end{array}$} & up to 40,000 & 6 & 10.00 & 35 & 58.34 \\
\hline & & $40,000-80,000$ & 16 & 26.67 & 21 & 35.00 \\
\hline & & Above 80,000 & 38 & 63.33 & 4 & 6.66 \\
\hline \multirow{4}{*}{10.} & \multirow{4}{*}{$\begin{array}{l}\text { Source of } \\
\text { irrigation }\end{array}$} & Bore well & 20 & 33.33 & 11 & 18.33 \\
\hline & & Canal & 16 & 26.66 & 27 & 45.00 \\
\hline & & Pond & 12 & 20.00 & 10 & 16.66 \\
\hline & & Others & 12 & 20.00 & 12 & 20.00 \\
\hline \multirow[b]{3}{*}{11.} & \multirow{3}{*}{$\begin{array}{ll}\text { Live } & \text { stock } \\
\text { position } & \end{array}$} & Low & 6 & 10.00 & 4 & 6.66 \\
\hline & & Medium & 41 & 68.33 & 47 & 78.33 \\
\hline & & High & 13 & 21.66 & 9 & 15.00 \\
\hline \multirow[b]{3}{*}{12.} & \multirow{3}{*}{$\begin{array}{l}\text { Mass media } \\
\text { exposure }\end{array}$} & Low & 11 & 18.33 & 22 & 36.66 \\
\hline & & Medium & 43 & 71.66 & 33 & 55.00 \\
\hline & & High & 6 & 10.00 & 5 & 8.33 \\
\hline \multirow[b]{3}{*}{13.} & \multirow{3}{*}{$\begin{array}{l}\text { Extension } \\
\text { contact }\end{array}$} & Low & 12 & 20.00 & 40 & 66.66 \\
\hline & & Medium & 40 & 66.66 & 10 & 16.66 \\
\hline & & High & 8 & 13.33 & 10 & 16.66 \\
\hline
\end{tabular}




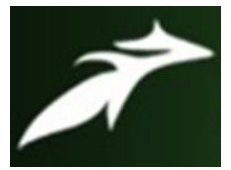

Poreddy Dileep et al, International Journal of Advances in Agricultural Science and Technology,

Vol.7 Issue.12, December-2020, pg. 1-8

ISSN: 2348-1358

Impact Factor: 6.057

NAAS Rating: 3.77

Table 2: KNOWLEDGE OF THE RESONDENTS ABOUT SERVICES THROUGH KISAN CALL CENTERS

\begin{tabular}{|c|c|c|c|c|c|c|c|}
\hline \multirow[t]{2}{*}{ S.NO } & \multirow[t]{2}{*}{ STATEMENT } & \multicolumn{3}{|c|}{ BENEFCIARIES } & \multicolumn{3}{|c|}{ NON-ENEFICIARIES } \\
\hline & & F.C & P.C & N. C & F.C & P.C & N.C \\
\hline 1 & $\begin{array}{l}\text { Do you know about telephone } \\
\text { /mobile number }\end{array}$ & $\begin{array}{l}52 \\
(86.66)\end{array}$ & $\begin{array}{l}6 \\
(10)\end{array}$ & $\begin{array}{l}2 \\
(3.33)\end{array}$ & $\begin{array}{l}54 \\
(90)\end{array}$ & $\begin{array}{l}3 \\
(5)\end{array}$ & $\begin{array}{l}3 \\
(5)\end{array}$ \\
\hline 2 & $\begin{array}{l}\text { Telephone / mobile can also be } \\
\text { used for calling, SMS internet. }\end{array}$ & $\begin{array}{l}58 \\
(96.66) \\
\end{array}$ & $\begin{array}{l}0 \\
(0)\end{array}$ & $\begin{array}{l}2 \\
(3.33) \\
\end{array}$ & $\begin{array}{l}53 \\
(88.33) \\
\end{array}$ & $\begin{array}{l}4 \\
(6.66) \\
\end{array}$ & $\begin{array}{l}3 \\
(5)\end{array}$ \\
\hline 3 & $\begin{array}{l}\text { Have you have know about } \\
\text { KCC }\end{array}$ & $\begin{array}{l}47 \\
(78.33)\end{array}$ & $\begin{array}{l}8 \\
(13.33)\end{array}$ & $\begin{array}{l}5 \\
(8.33) \\
\end{array}$ & $\begin{array}{l}41 \\
(68.33)\end{array}$ & $\begin{array}{l}3 \\
(5) \\
\end{array}$ & $\begin{array}{l}16 \\
(26.66)\end{array}$ \\
\hline 4 & $\begin{array}{l}\text { Do you know about } \mathrm{KCC} \\
\text { contact number }\end{array}$ & $\begin{array}{l}49 \\
(81.66)\end{array}$ & $\begin{array}{l}0 \\
(0)\end{array}$ & $\begin{array}{l}11 \\
(18.33)\end{array}$ & $\begin{array}{l}28 \\
(46.66)\end{array}$ & $\begin{array}{l}12 \\
(20)\end{array}$ & $\begin{array}{l}20 \\
(33.33)\end{array}$ \\
\hline 5 & $\begin{array}{l}\text { What do you know about } \\
\text { objectives of KCC }\end{array}$ & $\begin{array}{l}40 \\
(66.66)\end{array}$ & $\begin{array}{l}9 \\
(15)\end{array}$ & $\begin{array}{l}11 \\
(18.33)\end{array}$ & $\begin{array}{l}22 \\
(36.66)\end{array}$ & $\begin{array}{l}32 \\
(53.33)\end{array}$ & $\begin{array}{l}6 \\
(10)\end{array}$ \\
\hline 6 & $\begin{array}{l}\text { The location of } \mathrm{KCC} \text { in } \\
\text { Telangana is at Hyderabad }\end{array}$ & $\begin{array}{l}47 \\
(78.33) \\
\end{array}$ & $\begin{array}{l}10 \\
(16.66)\end{array}$ & $\begin{array}{l}3 \\
(5)\end{array}$ & $\begin{array}{l}46 \\
(76.66)\end{array}$ & $\begin{array}{l}2 \\
(3.33)\end{array}$ & $\begin{array}{l}12 \\
(20)\end{array}$ \\
\hline 7 & $\begin{array}{l}\text { The KCC service is available } \\
\text { from } 6.00 \mathrm{am} \text { to } 10.00 \mathrm{pm}\end{array}$ & $\begin{array}{l}12 \\
(20)\end{array}$ & $\begin{array}{l}39 \\
(65)\end{array}$ & $\begin{array}{l}9 \\
(15)\end{array}$ & $\begin{array}{l}37 \\
(61.66)\end{array}$ & $\begin{array}{l}8 \\
(13.33)\end{array}$ & $\begin{array}{l}15 \\
(25)\end{array}$ \\
\hline 8 & $\begin{array}{l}\text { KCC provides information in } \\
\text { holiday also }\end{array}$ & $\begin{array}{l}42 \\
(70)\end{array}$ & $\begin{array}{l}2 \\
(3.33) \\
\end{array}$ & $\begin{array}{l}6 \\
(10) \\
\end{array}$ & $\begin{array}{l}32 \\
(53.33) \\
\end{array}$ & $\begin{array}{l}9 \\
(15)\end{array}$ & $\begin{array}{l}19 \\
(31.66)\end{array}$ \\
\hline 9 & $\begin{array}{l}\text { KCC provides information in } \\
\text { regional languages }\end{array}$ & $\begin{array}{l}44 \\
(73.33)\end{array}$ & $\begin{array}{l}10 \\
(16.66)\end{array}$ & $\begin{array}{l}6 \\
(10)\end{array}$ & $\begin{array}{l}36 \\
(60)\end{array}$ & $\begin{array}{l}7 \\
(11.66)\end{array}$ & $\begin{array}{l}17 \\
(28.33)\end{array}$ \\
\hline 10 & $\begin{array}{l}\text { KCC provides all the } \\
\text { information in agriculture }\end{array}$ & $\begin{array}{l}38 \\
(63.33) \\
\end{array}$ & $\begin{array}{l}14 \\
(23.33)\end{array}$ & $\begin{array}{l}8 \\
(13.33)\end{array}$ & $\begin{array}{l}21 \\
(35)\end{array}$ & $\begin{array}{l}6 \\
(10)\end{array}$ & $\begin{array}{l}33 \\
(55)\end{array}$ \\
\hline 11 & $\begin{array}{l}\text { KCC provide SMS service to } \\
\text { the farmers }\end{array}$ & $\begin{array}{l}35 \\
(58.33)\end{array}$ & $\begin{array}{l}10 \\
(16.66)\end{array}$ & $\begin{array}{l}15 \\
(25)\end{array}$ & $\begin{array}{l}19 \\
(31.66)\end{array}$ & $\begin{array}{l}3 \\
(5)\end{array}$ & $\begin{array}{l}38 \\
(63.33)\end{array}$ \\
\hline 12 & $\begin{array}{l}\text { KCC provide conference call } \\
\text { facility }\end{array}$ & $\begin{array}{l}25 \\
(41.66) \\
\end{array}$ & $\begin{array}{l}25 \\
(41.66) \\
\end{array}$ & $\begin{array}{l}10 \\
(16.66) \\
\end{array}$ & $\begin{array}{l}24 \\
(40) \\
\end{array}$ & $\begin{array}{l}8 \\
(13.33) \\
\end{array}$ & $\begin{array}{l}28 \\
(46.66) \\
\end{array}$ \\
\hline 13 & $\begin{array}{l}\text { Do you know the name of } \\
\text { agency governing } \mathrm{KCC} \text { in our } \\
\text { state }\end{array}$ & $\begin{array}{l}15 \\
(25)\end{array}$ & $\begin{array}{l}37 \\
(61.66)\end{array}$ & $\begin{array}{l}8 \\
(13.33)\end{array}$ & $\begin{array}{l}13 \\
(21.66)\end{array}$ & $\begin{array}{l}19 \\
(31.66)\end{array}$ & $\begin{array}{l}28 \\
(46.66)\end{array}$ \\
\hline 14 & $\begin{array}{l}\text { Do you know about provision } \\
\text { of special facility of post of } \\
\text { KCC }\end{array}$ & $\begin{array}{l}12 \\
(20)\end{array}$ & $\begin{array}{l}16 \\
(26.66)\end{array}$ & $\begin{array}{l}32 \\
(53.33)\end{array}$ & $\begin{array}{l}16 \\
(26.66)\end{array}$ & $\begin{array}{l}11 \\
(18.33)\end{array}$ & $\begin{array}{l}33 \\
(55)\end{array}$ \\
\hline 15 & $\begin{array}{l}\text { knowledge about weather } \\
\text { conditions. }\end{array}$ & $\begin{array}{l}23 \\
(38.33)\end{array}$ & $\begin{array}{l}28 \\
(46.66)\end{array}$ & $\begin{array}{l}9 \\
(15)\end{array}$ & $\begin{array}{l}7 \\
(11.66)\end{array}$ & $\begin{array}{l}13 \\
(21.66)\end{array}$ & $\begin{array}{l}40 \\
(66.66)\end{array}$ \\
\hline
\end{tabular}




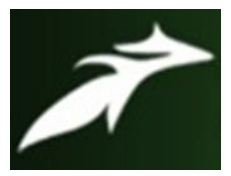

Poreddy Dileep et al, International Journal of Advances in Agricultural Science and Technology,

Vol.7 Issue.12, December-2020, pg. 1-8

ISSN: 2348-1358

Impact Factor: 6.057

NAAS Rating: 3.77

Table.3: OVERALL KNOWLEDGE LEVEL OF THE RESPONDENTS

\begin{tabular}{|c|c|c|c|c|c|c|c|c|c|}
\hline \multirow[t]{2}{*}{ S .No } & \multirow[t]{2}{*}{ Knowledge } & \multicolumn{4}{|c|}{ BENEFICIARY } & \multicolumn{4}{|c|}{ NON-BENEFICIARY } \\
\hline & & Number & Percentage & Mean & SD & Number & Percentage & Mean & SD \\
\hline 1 & Low & 8 & 13.33 & \multirow{3}{*}{35.98} & \multirow{3}{*}{6.04} & 17 & 28.33 & \multirow{3}{*}{33.12} & \multirow{3}{*}{7.69} \\
\hline 2 & Medium & 33 & 55.00 & & & 31 & 51.66 & & \\
\hline 3 & High & 19 & 31.66 & & & 12 & 20.00 & & \\
\hline Total & & 60 & 100 & & & 60 & 100 & & \\
\hline
\end{tabular}

The data presented in the Beneficiary respondents shows that majority of the respondents $(55.00 \%)$ had medium level of knowledge about the Kisan Call Center, while $31.66 \%$ of respondents had high and $13.33 \%$ of respondents had low level of Kisan Call Center, respectively.

Non- Beneficiary respondents shows that majority of the respondents $(51.66 \%)$ had medium level of knowledge about the Kisan Call Center, while $28.33 \%$ of respondents had low and $20 \%$ of respondents had high level of Kisan Call Center, respectively.

Table 4: Relationship between independent variables and knowledge level of kisan call centers

\begin{tabular}{|c|c|c|c|}
\hline \multirow[t]{2}{*}{$\begin{array}{l}\text { Sl. } \\
\text { No. }\end{array}$} & \multirow[t]{2}{*}{$\begin{array}{l}\text { Independent } \\
\text { Variables }\end{array}$} & \multicolumn{2}{|c|}{$\begin{array}{c}\text { Knowledge } \\
\text { Correlation co-efficient (r) }\end{array}$} \\
\hline & & Beneficiaries & Non- Beneficiaries \\
\hline 1 & Age & $0.09 \mathrm{NS}$ & $-0.037 \mathrm{NS}$ \\
\hline 2 & Education & $0.042 * *$ & $0.250 \mathrm{NS}$ \\
\hline 3 & Occupation & $-0.068 \mathrm{NS}$ & $-0.109 \mathrm{NS}$ \\
\hline 4 & Caste & $-0.080 \mathrm{NS}$ & $0.380 * *$ \\
\hline 5 & Family type & $-0.025 \mathrm{NS}$ & $-0.264 *$ \\
\hline 6 & Family size & $0.025 *$ & $-0.454 * *$ \\
\hline 7 & Type of house & $-0.030 \mathrm{NS}$ & $0.276^{*}$ \\
\hline 8 & Land holding & $-0.146 \mathrm{NS}$ & $-0.094 \mathrm{NS}$ \\
\hline 9 & Income & $-0.115 \mathrm{NS}$ & $-0.536 * *$ \\
\hline 10 & Source of irrigation & $0.091 * *$ & $-0.669 * *$ \\
\hline 11 & Livestock possession & $-0.149 \mathrm{NS}$ & $-0.079 \mathrm{NS}$ \\
\hline 12 & Mass media exposure & $0.065 * *$ & $-0.768 * *$ \\
\hline 13 & Extension contact & $0.169 \mathrm{NS}$ & $-0.374 * *$ \\
\hline
\end{tabular}




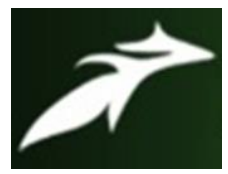

Poreddy Dileep et al, International Journal of Advances in Agricultural Science and Technology, Vol.7 Issue.12, December-2020, pg. 1-8

ISSN: 2348-1358

Impact Factor: 6.057

NAAS Rating: 3.77

\section{Knowledge:}

\section{Beneficiaries:}

The correlation coefficients of 13 independent variables with the knowledge of the beneficiaries farmers are presented in the Table 4.

Education (0.042), Source of irrigation (0.091), and Mass media expose (0.065) are found significantly correlated at 0.01 level of probability with the Beneficiaries knowledge about Kisan Call Center. Thus, it rejects the null hypothesis. So it can be concluded that education, source of irrigation, and mass media expose influence the Beneficiaries knowledge level of the respondents about Kisan Call Center.

Family size (0.025) is found significantly correlated at 0.05 level of probability with the beneficiaries knowledge of the respondents towards use of Kisan Call Center. Thus, it rejects the null hypothesis. So it can be concluded that Family size is influence the beneficiaries knowledge of the respondents towards the use of Kisan Call Center. However, the Age (0.09NS) and extension contact $(0.169 \mathrm{NS})$ are positively and non-significantly correlated with Beneficiaries knowledge about Kisan Call Center. Thus, it accepts the null hypothesis. So it can be concluded that age and Extension contact are not influence the Beneficiaries knowledge level of the respondents about Kisan Call Center.

Whereas, Occupation (-0.068NS), Caste (-0.080NS), Family Type(-0.025NS) Type of House (-0.030NS), Land Holding (-0.146NS), Income (-0.115)and Livestock Possession (-0.149NS) are negatively and non-significantly correlated with Beneficiaries knowledge about Kisan Call Center. Thus, it accepts the null hypothesis. So it can be concluded that Occupation, Religion, Family Type, type of House, Land holding, Income and Livestock possession are not influence the Beneficiaries knowledge level of the respondents about Kisan Call Center.

\section{Non-beneficiaries:}

The correlation coefficients of 13 independent variables with the knowledge of the nonbeneficiaries farmers are presented in the Table 4.

It could be observed from the Table .4 the variables such as Type of house $\left(0.283^{*}\right)$, had positive and significant relationship with knowledge gain by the farmers at five per cent level of significance. Caste $\left(0.368^{* *}\right)$ had positive and significant relationship with non- beneficiaries knowledge gain by farmers at one percent level of significance. Family size $\left(-0.501^{* *}\right)$, Income 


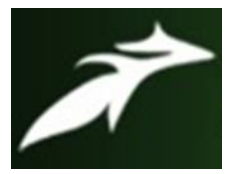

Poreddy Dileep et al, International Journal of Advances in Agricultural Science and Technology,

Vol.7 Issue.12, December-2020, pg. 1-8

ISSN: 2348-1358

Impact Factor: 6.057

NAAS Rating: 3.77

$\left(-0.595^{* *}\right)$, Source of irrigation $\left(-0.570^{* *}\right)$, Mass media exposure $\left(-0.825^{* *}\right)$, and Extension contact $\left(-0.748^{* *}\right)$, had negative and significant relationship with non-beneficiaries knowledge gain by the farmers at one per cent level of significance. Whereas, other variables such as age, education, occupation, family type, land holding, and livestock possession found to have nonsignificant relationship with knowledge gain of farmers.

\section{CONCLUSION:}

It was found that overall knowledge regarding KCCs in beneficiary had medium level of knowledge and non beneficiary had medium to low level of knowledge of KCCs.

\section{REFERENCES}

[1].Pawar et al.(2011) revealed that 88.34 percent of the respondents had high level of knowledge about computer followed by 11.36 per cent medium level of knowledge about computer.

[2].Sharma et al.(2012) revealed that 56.87 per cent that of the respondents had favorable attitude and 26.66 per cent respondents had most favorable attitude towards kisan mandal and kisan sewa Kendra.

[3]. Verma et al. (2012) revealed that 56.87 per cent of the respondents had favorable attitude and 25.63 per cent had most favorable attitude towards ICT application in agriculture.

[4].Kumar et al. (2013) found majority of the beneficiaries (72.50 per cent) were belonged to joint families and rest 27.50 per cent beneficiaries belonged to the nuclear families.

[5].Rudroju et al.(2013) revealed that majority of the farmers (74.29\%) had suggested for providing them training in operating ICT tolls, providing adequate knowledge of various ICTs projects (67.86\%) and linking ICT projects with other services $(61.43 \%)$.

[6].Singh et al (2013) found that constraint availability of the handsets compatible to the local languages of the farmers and timely reading the messages by the e-farmers.

[7]. Wayne et al. (2013) conducted a study regarding the attitude of farmers towards a participatory research method and reported that age, education and farming experience were found significant relationship with attitude towards a participatory research method used to evaluate weed management strategies in bananas at one per cent level and land holding was found significant at five per cent level of probability. 